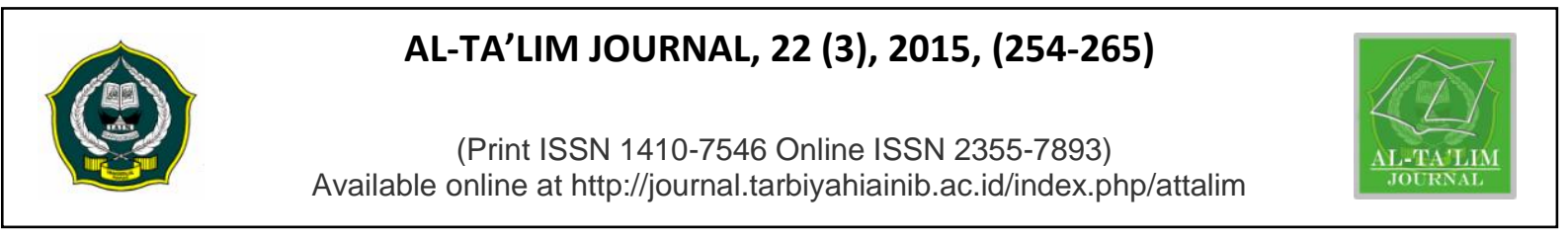

\title{
The Use of Virtual Media Laboratory to Increase Students' Motivation on Direct Current Circuits Materials at Class X of MAN I Pekanbaru
}

\author{
EMHADELIMA
}

E-mail : emhadelima@gmail.com

Received: 12th June 2015; Revised: 20th July 2015; Accepted: 24th July 2015

\begin{abstract}
The purpose of the study is to determine whether there is a significance effect on the use of Practicum methods by using Crocodile Program combined with lectures, question and answer activities give significant effect on students' activities in learning electricity simple lesson and to identify whether the use of the simulation lab provides better results than the traditional lab on learning outcomes. 36 natural science students was involved in the study. The data was analyzed by using t-test. The finding showed that the use of Practicum methods by using Crocodile Program combined with lectures; question and answer activities give significant effect on students' activities in learning electricity simple lesson. The finding also showed that the use of the simulation lab can provide better results than the traditional lab on learning outcomes. It occurred when there is an adequate software capability and students can operate the software properly. Without taking into account about the cost of procurement of computers and software programs Crocodile, lab simulations are very low cost because it does not need to purchase laboratory equipment, supplies and other consumables. It is expected that Crocodile Program not only as a practical method to implement but also as a medium to explain the concepts of electronic circuits.
\end{abstract}

Key words: Virtual Media, Circuits Materials.

How to Cite: Emhadelima. (2015). The Use of Virtual Media Laboratory in Increasing Students' Motivation in Learning Physics on Direct Current Circuits Materials in Class X MAN I Pekanbaru. Al-Ta Lim, 22(3). doi:http://dx.doi.org/10.15548/jt.v22i3.147

Permalink: DOI: http://dx.doi.org/10.15548/jt.v22i3.147

\section{INTRODUCTION}

Physics is part of natural science (IPA), which is essentially defined as a collection of knowledge, the ways of thinking, and investigation. IPA as a collection of knowledge can be in the form of facts, concepts, principles, laws, theories, and models. IPA as a way of thinking is an activity that goes on in the minds of people who are involved in it because of their curiosity and desire to understand the natural phenomena. IPA as a way of investigation is the way scientific information is obtained, tested, and validated.
IPA is taught in every elementary and secondary education. But in the delivery and transferring of the knowledge there are many obstacles found. From the observation that the author did, it was found some problems in learning physics in Islamic Senior High School or Madrasah Aliyah Negeri 1 Pekanbaru. the problem found is also a problem that is commonly found in the teaching of physics in other Madrasah in Indonesia. They are:

1. Learning physics is considered as being too academic so that students hardly have 
the opportunity to actualize themselves, their ideas and the concepts they have.

2. Commonly, physics is presented only as a mere collection of formulas to be memorized by students, finally when the teacher evaluated the lesson, the formula becomes tangled in the minds of students.

3. In conveying the material, there is less attention to the proportion of the material and systematic delivery, and also it put little emphasis on the basic concepts so that, it made students difficult to understand.

4. The lack of variety in teaching as well as infrequent use of tool that can clarify the description of the students on the material being studied.

5. The tendency to complicate, rather than simplify. This is often done in order the students do not underestimate the lessons of Physics and Physics teacher himself/herself.

6. learning methods used were less able to motivate students to ask

7. the material given to the students is an advanced knowledge of material that has been prepared and is not a material concerning to daily life

8. Lack of an integrated concept among other science

9. Lack of specific devices and lab tools on learning physics at Madrasah.

10. The lack of ability of the teachers in the mastery of technology

Related to the problem above, physics is seen as a process and product at the same time so that the learning should consider strategies or methods that effectively and efficiently. One of the strategy or method is through practical activities. Through practical activities, students perform well by using mind and hand. Yet, to make the physics class become more interesting and fun not only from the learning method but also tools in the laboratory tools supporting the practical lesson.

Practicum in teaching physics has a role as a motivation in learning, giving students the opportunity to develop a number of skills, and improve the quality of student learning. Considered to the practical activities in Madrasah, it was found that the practicum tools were inadequate and damaged, it caused frequent trouble in practicum activities in Madrasah, the Damage of the practical tool is not comparable with the procurement of labor each year.

\section{LITERATURE REVIEW}

\section{The Nature of Physics and the Results of Studying Physics}

Physics at Madrasah aims to use physics as a vehicle for understanding the physics concepts and their interrelationships, and also be able to apply the concepts of physics in scientific methods that involve the process skills to solve the problems in everyday life and develop attitudes and values of science. Thus, learning physics in Madrasah includes the process of giving understanding of physics concepts, developing the ability to solve problems by understanding concepts, developing skills and the ability to execute experiments, developing attitudes and values of science, developing interest and motivation, introducing the use of physics in daily life and technology. Teaching and learning processes in Physics at least include transferring information and understanding of the concept, doing practice questions and performing experiments in the laboratory. However, the teaching learning process of physics often found in the field did not attempt an understanding of physics concepts, but rather providing information about the symptoms of physics and equations and practice how to use these formulas. Therefore, the students just get used to memorize formulas without understanding its meaning.

Learning outcomes is a process for determining the value of student learning through assessment or measurement of learning outcomes (Dimyati and Mudjiono, 1999). Measurement of learning outcomes can be determined by using a test gauge. Arikunto (1993) stated learning outcomes is a 
result obtained by the students following the learning process. The results are usually expressed in the form of numbers, letters or words very good, good, fair, less, and failed. Dimyati and Mujiono (1999: 18) states that learning is an internal complex process. This internal process involved the whole mental that includes cognitive, affective and psychomotor.

Bloom (1956) cited by Ratna (1988) has explained that the learning outcomes are demonstrated objectives or expected behavior to be achieved in teaching a subject matter that has been formulated in specific instructional objectives.

The learning process actualizing these values is focused on specific learning materials. Learning is to acquire knowledge, skills and planting mental attitude and values. The achievement of learning objectives will produce better learning outcomes. The Ability as a result of learning can be grouped into five categories: 1) intellectual skills, 2) Cognitive Strategy, 3) verbal information, (4) motoric skill and (5) an attitude. (Gagne, 1989). Intellectual skills are an ability that allows a person to interact with the environment through the use of symbols or ideas, so that with the intellectual skills, one may know how to do something by using his thoughts. Ratna revealed that learning intellectual skills has been started since the first levels of primary school and continued by appropriate attention and intellectual abilities of a person. Cognitive strategies are specific intellectual skills that have a particular interest for learning and thinking. Cognitive strategy is a process that controls the internal processes used by students to choose and change the ways of paying attention, learning, remembering and thinking. Verbal information is often also called verbal knowledge is related to the ability to remember the information received, the words which were spoken by person, the reader, listener and watcher. Verbal information is the result of learning at school and in the family, and this is a technique used by students to focus and sustain attention, to control the anger and use time effectively. Motoric skills are the abilities related to physical activities like driving a car, cycling and so on. It is added by Gagne (cited in Ratna (1988)), motoric skills includes not only physical activity, but it is combined with the intellectual skills, such as reading, writing, using a microscope and others. The last is attitude. Attitude can affect a person's behavior towards objects and other events. Attitude refers to an action that is characterized by positive and negative reactions.

Romiszowski (1981) reported the learning achievement was obtained from knowledge and skills. The Knowledge is grouped into four sections, namely, facts, concepts, procedures and principles. Knowledge is all the information that is captured by someone's senses and then stored in the brain. Skills are an act or behavior of a person who is able to show a sign of the skilled person. The fact is a real object, the association of the fact that acquired through observation. This is processed and presented by scientists being the data. The concept is an idea or a notion that generalized from certain relevant experiences. Principle is a generalization that includes concepts which are related and quality, correlation or axiomatic. The procedure is the knowledge of doing the actions step by step that are linear or vary in achieving a goal. The essence of learning is the students' actions and behavior which are complex. Students are the determinant in the learning process effectively and efficiently. Students learning are driven by curiosity or necessity.

Learning outcomes should be effective, efficient and attractive. Effectiveness is measured from the level of student achievement both in quality and quantity; efficiency is measured by time needed by the students to learn, while the attractiveness is measured whether or not there is the tendency of students' motivation to learn more (Reigeluth, 1983). As the characteristics of effective learning include (1) the achievement of the learning program, (2) changes in 
behavior, (3) a conducive learning conditions, (4) the role of the teacher as facilitator, (5) the use of appropriate time and (6) the student as the subject of study. Effectiveness was measured by the achievement of student learning outcomes. Dimyati and Mujiono (1999) that studying physical knowledge, knowledge of mathematical logic and social sciences includes three phases: (1) exploration (2) experience of the concept and, (3) application of the concept. In the exploration phase students learn the symptoms with the guidance, then, the experience concept. In this phase, the students recognize the concept that there is a relationship with the symptoms. In the application phase of concepts, students use the concepts to conduct further investigation on the other symptoms. Information about the objectives study, reinforcement, evaluation and learning success will lead students to be aware of their abilities. According to Sardiman (2000) the results study includes, (a) matters of science and knowledge, concepts or facts (cognitive), (b) personal affairs, personality or attitude (affective), and (c) matters of behavior, skills (psychomotor).

The Teacher planned in learning activities outlined in the learning program is lead to the success of the students. This reinforces the desire to become more independent in learning to achieve the learning goals and to achieve a level of independence. Teachers arrange learning events and try to reach the goal of learning, to improve the cognitive abilities, effective and psychomotor, in achieving the goal of the education or the learning. According to Bloom (1961), quoted by Dimyati and Mujiono (1999) there are facts, concepts, theories in a particular subject, or have priority on using method of solving the problems such as the use of formulas, learning tools, and the discovery process skills approach.

The learning outcomes covered three domains include the cognitive, affective and psychomotor. To measure the learning outcomes, it is required measurement or the so-called achievement test. The test results are then expressed in the form of numbers, letters or words very good, good, fair, less, and failed.

Physics is a subject that is difficult for most students and many studies show that student learning outcomes in these subjects is very low. Thus the teacher must firstly understand the characteristics of the physic subjects. This is as proposed by Beiser and Addison (1972) who states that physics is the science of matter and this is a kind of understanding of the nature and behavior of the fundamental structure. As a science, it has also shown that physical linkages with other sciences. Furthermore, Morris Kline in Suriasumantri (2001) stated that the physical characteristics include laws, the principle that can be done by induction or experiments.

In addition, Kane (1978) states that the concept of physics presents rules and laws / proposition. Therefore one of the approach to define the concept of physics is the physicists have to really try to understand the rules and laws / proposition. Also, Anderson and Kautnik (1972) describe one of the characteristics of good teaching and relevant to science is that teachers should first think about the subject matter to be taught or to be given to students.

The other characteristics of physics is through the subjects of physics, students are expected to gain experience in the form of reasoning ability and mathematical quantitative deductive based on a qualitative analysis by using various concepts of physics. (Depdiknas, 2001). For this reason, Kember (2001) explains that efforts to improve learning outcomes require a wide variety of student learning approaches. This means that the ability of the teachers and the students' performance. The performance of the teacher should be innovative in their performance.

Budikase and Kertiasa (1995) states that physics is a science that requires a lot more understanding than memorizing, so that, the students can be said successful in learning physics when he was able to master the three main points in physics, namely the concepts, 
principles and theories. A student can be said understand the physic lesson if the student can demonstrate its ability to implement the principal of physics. Moreover, as stated by the Ministry of Education (2001) that after the students follow courses in physics, the students are expected to have the ability and attitude such as: (1) positive attitude toward science of physics as a quantitative basis, (2) the ability to apply the concepts and principles of physics in explaining various natural phenomena as well as the workings of technology, and how to solve problems, (3) the emergence of a scientific attitude, which is an open and critical attitude towards the other opinions, and not easily believe of the statement which is not supported by the empirical proof, and (5) the ability to study science at universities or attend various trainings that require basic skill of physics.

From the various opinions above, it can be concluded that a student is successful in learning physics if the student changes their point of view on physics, such as students can master the concepts, principles and principles of physics. Also, this knowledge can be applied to explain various phenomena

\section{Media}

According to Heinich (1993) media is a tool of communication channels. Media is derived from Latin and is the plural form of the word "medium" which literally means "intermediary" is an intermediary source of the message (a source) to the message receiver (a receiver). Heinich exemplifies this media such as movies, television, charts, printed material, computers, and instructors. The examples of media can be considered as a medium of learning if carrying messages in order to achieve learning objectives. Heinich also links between media messages and methods.

At the beginning of the learning history, a media is simply a tool that is used by a teacher to help the teacher in explaining lesson. The first tools used in teaching physics is visual aids, which can provide a visual experience to students, to encourage them to learn, to clarify and simplify abstract concepts, and to enhance absorption or retention of learning. Then, by the development of technology, particularly audio technology, in the middle of the 20th century it was born the tool of audio-visual aids which are primarily using concrete experience to avoid verbalism. In using the media as a tool, Edgar Dale held a classification according to the level of the most concrete to the most abstract.

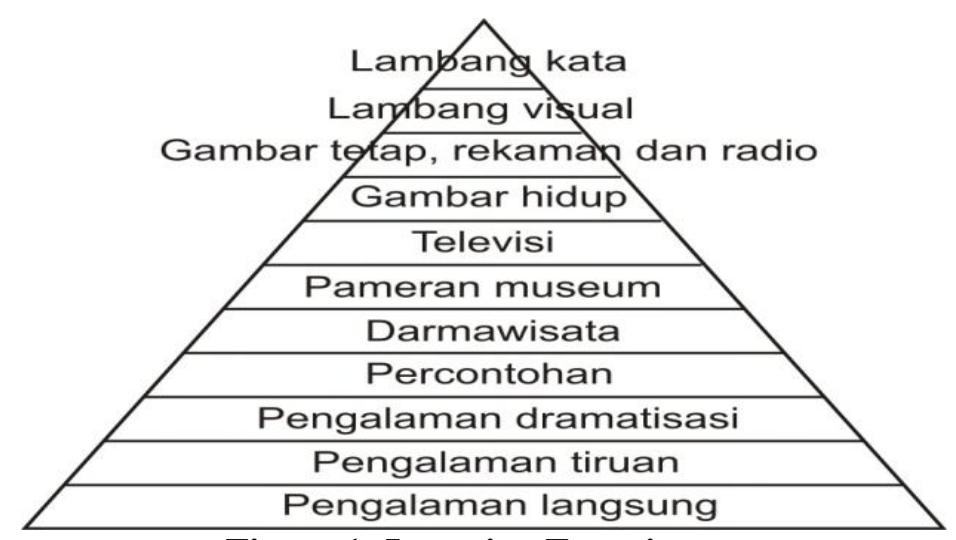

Figure 1: Learning Experiences

The above classification is known as the "cone of experience" from Edgar Dale and at the time, it was widely adopted in determining the most appropriate tools for the learning experience.
In the late 1950s the theory of communication began to affect the use of media, so that, the function of the media as handy tool also can be functioned as a sending message. Then, by the influence of the behavior theory by BF Skinner, since 
1960 learning objectives shifted toward the change of students' behavior, because according to this theory, people learning are by changing their behavior. A programmed learning is a product of Skinner's flow.

The development of instructional media is following the development of educational technology. If we analyzed further, the development paradigm in education technology affect the development of instructional media. They are as follows:

1. In the first paradigm, learning media is the same as audio-visual aids used by instructors to carry out their duties.

2. In the second paradigm, the media is seen as something that developed systematically and adhering to the rules of communication.

3. In the third paradigm, the media is seen as an integral part in the learning system and therefore calls for changes in the other components in the learning process.

4. Learning media, in the fourth paradigm, is seen as one of the sources who intentionally and aims to develop and or used for learning purposes.

Even a prominent American architect, Buckminster Fuller, in Haney \& Ulmer, stated that the media is the third parents (teachers are the second parents). Indonesia had already begun to use the trend by broadcasting education by private TV "Televisi Pendidikan "( Education Television) to the entire country since 1991.

With the conception of the more stable, the function of media in learning activities not only as aids for the teacher, but also as a carrier of information or messages that fit to the learning needs. Thus a teacher can focus its work on the other aspects such as individual guidance and counseling activities in the learning activities.

The acquisition of students' knowledge as depicted by Edgar Dale in Cone experience that the knowledge will be more abstract if the message conveyed through verbal word. This means that students only know about and understand the words without understanding the meaning. This sort of thing will lead to misperceptions of the students. Therefore, students should have more concrete experience so the message can actually achieve the goals and objectives. In general, the media have utility:

1. Clarify the message that is not too verbalistics.

2. Overcome the limitations of space, time, energy and resources senses.

3. Emerge the excitement in learning, direct interaction between pupils with learning resources.

4. Allow children to learn independently according to their talents and abilities of visual, auditory and kinesthetic.

5. Provide the same stimulus, likening the experience and creating the same perceptions.

In addition, the contribution of learning media according to Kemp and Dayton, 1985:

1. Delivering the learning message can be standardized

2. Learning can be more attractive

3. Learning becomes more interactive by applying learning theory

4. The timing of the learning can be shortened

5. Quality of learning can be improved

6. The process of learning can take place whenever and wherever it is needed

7. A positive attitude of students towards learning materials and the learning process can be improved

8. The role of the teacher change in a positive one

Instructional media functions can be emphasized from the following points:

1. The use of instructional media is not an additional function, but it has its own function as aids to create a more effective learning situations.

2. Learning media is an integral part of the overall learning process. This implies that the learning media as one of the components that does not stand alone but interconnected with other components in 
order to create learning situations as expected.

3. Learning media in its use should be relevant to the competency and learning content itself. This function implies that the use of media in teaching must always look to the competence and teaching materials.

4. Learning media does not serve as a means of entertainment, thus it is not allowed to use it just for a game or fishing the students' attention.

5. Learning media can serve to accelerate the learning process. This function means that the media can capture student learning objectives and teaching materials easier and faster.

6. Learning media serves to improve the quality of teaching and learning process. In general, the results of student learning using learning media will be kept in long term memory so that the quality of learning has a high value.

7. Learning media laid the foundation to think concretely, therefore, it can reduce the occurrence of disease verbal.

In addition to the functions described above, this learning media also have the value and benefits as follows:

1. Making abstract concepts becomes more real. The Concepts that is still perceived abstract and difficult to explain directly to the students can be made concrete or simplified through the use of instructional media. For example, to explain the blood human circulatory system, electric current, blow of the wind, etc. These could use an image media or a simple chart.

2. Carrying the objects that are too dangerous or difficult to come into the learning environment. For example, the teacher explained by using pictures or television program about the ferocious animals like tigers and bears, or other animals such as elephants, giraffes, dinosaurs, etc.

3. Displays objects that are too large or too small. For example, teachers will convey an idea of a ship, aircraft, markets, temples, etc. Or display objects that are too small as bacteria, viruses, ants, mosquitoes, or animal / other small objects.

4. Showing the movement which is too fast or slow. By using the technique of slow motion in movie media, it can show the trajectory of bullets, arrows boom, or show an explosion. Conversely, by using this technique, it can show the movements that are too slow as the growth of sprouts, blooms Wijaya Kusumah flower and others.

Virtual Media Laboratory, also known as dry Laboratory is the formation of virtual word that means not real, which can be simulated by computer software at certain times. Virtual word usually associated with virtual reality word, which means "a realistic simulation of an environment, Including three dimensional graphics, a computer system by using interactive software and hardware", (Random House Ster.s, 2000: 23). The word "virtual reality" can be interpreted as a realistic simulation of the environment, including three-dimensional graphics with a computer system that uses interactive software and hardware.

Another definition says that: Virtual Reality is a way to understand the real world that is created with the help of computers. Computer create a 3-dimensional computer image and sound effects (in the form of a stereo) particularly. The model is driven manually, and there are facilities for interaction between the user on-screen display, for example, in a 3-dimensional model of the earth. This 3-dimensional model provides a more realistic image than twodimensional models. Virtual model of the earth or the virtual earth is created by using a computer language called the language "VR". The language of this program can create 3dimensional model of an object. The emergence of two words Virtual and Laboratory can serve as a something abstract that is represented by a visual model to help the user in the simulation to obtain data on 
making a hypothesis. In this case the simulation taken from the word "stimulatory" is defined as media for testing an experiment or trial as if as the original one

\section{The Relationship of Virtual Media with Learning Motivation}

The laboratory that is in the form of software is run by a computer. All the equipment needed by a laboratory contained in the software. By having a computer lab and a variety of software simulation lab, it means that the school is that the school has a variety of other laboratories such as laboratories of physics, chemistry, biology, mathematics, language, art and others depending on the kinds of software owned.

One example of virtual laboratory software is Crocodile Program. By using Crocodile program we can make a variety of electronic circuits virtually on the computer screen, perform measurements, and perform various analyses on the circuit. Crocodile program is equipped with various input sources such as batteries, an AC voltage source, Vcc source, FM source; various basic components such as resistors, capacitors, relays, switches and transformers; various diodes including DIAC, triac, LED and Zener diodes; various indicators such as: voltmeter, ammeter, and a variety of other instruments.

\section{The Practical Simulation by using Crocodile Program}

Next, it will describe the author's experience in implementing virtual labs by using CROCODILE software to improve the analysis and design of electronic circuits on a student in a physics lab at MAN 1 Pekanbaru. One of the students' learning objectives electronics in Physical courses is to develop the ability to analyze the characteristics and to design electronic circuits for various applicable needed. Electronics has two main aspectsin learning, namely the theoretical aspects and practical aspects. Both of these aspects are interrelated, the ideas that produced theory cannot be given just by providing information, but it should provide a real experience through experimentation. As stated by Nurhadi (2002), knowledge is not a set of facts, concepts, or rules that are ready to be taken and remembered.

Humans must construct knowledge and give meaning through real experience. Yet, experiments in electronics require much cost because it takes a lot of components and instruments which are relatively expensive. Therefore, the electric practicum in physics in MAN 1 Pekanbaru was conducted using a panel system. On the panel system, a series that will be studied or characteristic has made permanently on the circuit board. Student task is to perform the measurement of various parameters on the circuit. The weakness of this system is students cannot change the value of the resistor and capacitor components into the variable shape; the panel made is very limited, the value of the component can be changed so it changes the output characteristics, and the students cannot design its own system and cannot modify the circuit. As a result, the student's ability in analyzing the characteristics and designing electronic circuits is low. To overcome the above problems, it can be used by simulating a software program called the Crocodile. By using CROCODILE PROGRAM we can make a variety of electronic circuits virtually on the computer screen, perform measurements, and perform various analyses on the circuit.

The aim of this study is to look at the effect of the use of simulation software lab using crocodile on students' ability to analyze and design the circuit electronics. Computers simulations have become a part of educational reformation, redefining the role of teachers and reshaping the learning experience in the classroom according to the National Science Education Standard (NSES) and the National Science Teachers Association (NSTA) (2001). Science simulation can be used as an effective tool to help students understand and apply the practical experience in scientific thinking (Akpan, 2001); Akpan \& Andre, 
2000; Coleman, 1988). A simulation is a dynamic execution of processes in which there is a system of object relations model. Thomas and Hooper (1991) described the simulation as a computer program containing the model manipulation system. The simulation program can receive commands from the user, change the state of a model, and display the new circumstances. According to Akpan (2001), the simulation must be designed with the intention to immerse students into real-life situation of science, experience hands-on activities, higher-order thinking, and collaborative problem solving.

Research on how and when the simulation is used to support other learning elements (didactic learning, collaborative, laboratory experience, assessment) will help to clarify how simulation can be used to obtain maximum impact in the classroom. Also, it will see the effect on students in carrying out tasks by using computer simulations before or after learning teaching process. These have been the attention of a number of research. It is found that computer simulations have the ability to present a realistic visualization and images and can create a constructive learning environment that improve student learning outcomes. According Zahorik (1995), knowledge is not the number of facts, concepts, or laws waiting to be discovered. Man must construct knowledge through the experience. The essence of the constructivist theory is the idea that students must discover and transform complex information into another situation, and if desired, the information belongs to their own (Nurhadi, 2002). The knowledge and skills acquired by students are expected not as a result of memorizing a set of facts, but as the result of finding themselves. Based on that theory, the learning process should be packed into a constructive knowledge not receiving knowledge. Simulation lab using PROGRAM CROCODILE allows students to construct their own knowledge.

In the learning process, students construct their own knowledge through active involvement in the learning process. Teachers designed the program referring to the activities discovered. Teachers allowed students to find and apply his own. Teacher's job is to facilitate the process. Learning emphasizes on helping students to be able to learn how to learn. The improvement of Study was assessed from the process and the results of the questionnaire.

Practical implementation is a simulation that does not use the actual components and circuits but using virtual circuits and virtual measuring devices that display on a computer screen by using the software program Crocodile.

The forms of learning activities were practical, response, designing projects using PROGRAM CROCODILE and conducting an analysis of the design. The topics of the lesson are: Electrical circuit arrangement in the simple form of series and parallel circuits to determine the value of strong currents and voltages. The task of designing and analyzing the results of the design is done individually.

Broadly speaking, the steps of learning activities were as follows.

1. The teacher provided introductory material for topics: Electric Circuits of direct current using resistors, batteries, ampermeter and voltmeter.

2. Students were individually designed a simple electrical circuit with the help of computers using the software CROCODILE PROGRAM.

3. Students analyzed the results of the characteristics design of the circuit by performing measurements of various parameters of virtual circuits (among others: strong current, voltage and power).

4. Students reported the results of the design and the results of the analysis as well as answering questions posed by the teacher about the simulation project created.

5. Students make conclusions.

\section{METHOD}

The descriptive study used in this research. 36 natural science students were 
involved in the study. The data was analyzed by using t-test.

\section{RESEARCH FINDINGS AND DISCUSSION}

The results of the implementation of learning by using CROCODILE PROGRAM is obtained from the observation during the students carried out practice and analytical skills test circuit and test of the ability of designing circuits in writing. The indicators of the ability in conducting an analysis of electronic circuits is determined by the ability of using various parameters on the circuit as the strong current, voltage and power at certain points, in a circuit and others. Indicator of the ability to design circuits includes the ability to plan a series of series and parallel well. The good chain will be able to produce the correct current and voltage.

From the observation and statistical analysis of data was obtained data asshown in Table Simulation lab using Crocodile Program with lab using both panel on boys and girls. Simulation lab using Crocodile Program gives a better effect than the lab using a panel method for both the boys and girls. From the learning activities and observations, the data were obtained as follows:

1. Lessons can be started in accordance with the specified schedule

2. When a discussion is conducted with students about physics lessons, most students encountered difficulties in learning physics because of several problems that become common problems of learning physics in Indonesia as has been shown in the background.

3. When the delivery of content by using the Crocodile Program and combining with the method of question and answer, to explain what the circuit in series and parallel.

4. What the advantages and disadvantages of each form of the circuit were.

5. Determine the amount of component values, strong currents and voltages occurred.

6. When applying it in the form of test, it was found the difficulties because of poor math skills.

7. When giving exercises on simple electric circuit, the students found difficulties to finish it but it could be overcome because they were helped by some students who have sufficient math skills, teachers and other colleagues.

Based on the observations at the first activities, the general implementation of learning can be carried out in accordance with the teaching plan that has been made. Based on the observation of the students, it was found that students are more active and motivated in learning activities and are very interested with the displayed tools.

Based on the initial questionnaire given to students before teachers starting a lesson, the data were obtained as follows:

Table 1: The Percentage of the Result of the Initial Questionnaire

\begin{tabular}{l|l|l|l|l|l}
\hline No & \multicolumn{1}{c|}{ Statement } & \multicolumn{5}{c}{ Percentage } \\
\cline { 3 - 6 } & & SA & A & NA & SNA \\
\hline 1 & The students had ever studied the material & 40 & 40 & 20 & - \\
\hline 2 & The students enjoyed the lesson & 45 & 55 & & - \\
\hline 3 & $\begin{array}{l}\text { The students felt that they had understood the } \\
\text { lesson }\end{array}$ & 5 & 50 & 30 & 15 \\
\hline 4 & $\begin{array}{l}\text { The students preferred studying alone than asking } \\
\text { friends }\end{array}$ & & 20 & 65 & 15 \\
\hline 5 & $\begin{array}{l}\text { The students preferred studying alone than asking } \\
\text { to the teacher }\end{array}$ & & 20 & 10 & 70 \\
\hline 6 & $\begin{array}{l}\text { The students preferred asking to the friends than to } \\
\text { teacher }\end{array}$ & & 15 & 70 & 15 \\
\hline 7 & The students didnot pay attention to the lesson & & & 50 & 50 \\
\hline
\end{tabular}


Note: The number of students who filled out the questionnaire was 36 students

From the table I, it can be seen that $80 \%$ of students stated they had got the lesson on the simple electronics though the level of understanding of it was still low. Only $55 \%$ of students stated that only understand the material presented. It means there are $45 \%$ of students who do not understand the lesson presented. While the level of interest or concern and pleasure students to the lesson was high reaching $100 \%$ (point 7) and $100 \%$ (point 2). Additional information obtained from the above data is that students like to ask questions and learn the teacher and friend rather than learning by themselves (point 6) though some students still expressed more enjoyable learning to the friend than that to teachers.

Based on the final questionnaire given to the students after learning activities, obtained the following data :

Table 2: The Percentage of the Result of the Final Questionnaire

\begin{tabular}{|c|c|c|c|c|c|}
\hline \multirow[b]{2}{*}{ No } & \multirow[t]{2}{*}{ Statement } & \multicolumn{4}{|c|}{ Percentage } \\
\hline & & SA & $\mathrm{A}$ & NA & SNA \\
\hline 1 & The students had ever studied the material & 35 & 65 & - & - \\
\hline 2 & The students enjoyed the lesson & 40 & 50 & - & - \\
\hline 3 & The students felt that they had understood the lesson & 15 & 65 & 15 & 5 \\
\hline 4 & The students felt easier in understanding the lesson & 20 & 70 & 10 & - \\
\hline 5 & $\begin{array}{l}\text { The students preferred studying alone than asking } \\
\text { friends }\end{array}$ & & 35 & 50 & 15 \\
\hline 6 & $\begin{array}{l}\text { The students preferred studying alone than asking to } \\
\text { the teacher }\end{array}$ & - & 20 & 60 & 20 \\
\hline 7 & $\begin{array}{l}\text { The students felt the help of the teacher to comprehend } \\
\text { the lesson }\end{array}$ & & - & 35 & 65 \\
\hline 8 & $\begin{array}{l}\text { The students preferred asking to the friends than to } \\
\text { teacher }\end{array}$ & - & 15 & 50 & 35 \\
\hline 9 & The students didnot pay attention to the material & - & & 35 & 65 \\
\hline 10 & The students liked the way of the teacher teaching & 70 & 30 & - & - \\
\hline 11 & The students do not pay attention to the lesson & - & - & 30 & 70 \\
\hline
\end{tabular}

From the table above, it can be seen that generally students of class XII IPA 1 in MAN 1 Pekanbaru have positive attitudes towards the use of learning by inquiry model with emphasizing practice method by using Crocodile Program and also combined with lectures, discussions, and question and answer. With the model of the lesson, students easily understood the material presented. The level of understanding of students has increased from $55 \%$ to $80 \%$.

The time required to carry out the experiment is much shorter compared to using actual components. In the same time, the output of parameters of the design can be immediately known and the circuit can be immediately repaired or value of the components can be replaced immediately if the output of the circuit is not in accordance with desired.

Based on the results of questionnaires known that students felt freely and creatively to design a variety of electronic circuits without having to take into account the cost of purchasing the components.

\section{CONCLUSION AND RECOMMENDATION}

It can be concluded that the use of Practicum methods by using Crocodile Program combined with lectures, question and answer brings significant effect on students' activities in learning activities in electricity simple lesson. 
The use of the simulation lab can provide better results than the traditional lab on learning outcomes. it occurred when there is an adequate software capabilities and students can operate the software properly. Without taking into account about the cost of procurement of computers and software programs Crocodile, lab simulations are very low cost because it does not need to purchase laboratory equipment, supplies and other consumables.

In the case of Crocodile Program, students felt very free and creative to design a variety of electronic circuits without having to take into account the cost of purchasing the components. However, students who did not master at using the software program Crocodile found it difficult to design an electronic circuit and analyzed its output. Therefore, before carrying out the simulation lab with Crocodile Program, the student must firstly be trained using Crocodile Program. Yet, Students should know first or skillfully use the actual measuring instrument such as an oscilloscope before using virtual gauges. Students expected Crocodile Program not only as a practical method to implement but also as a medium to explain the concepts of electronic circuits.

In accordance with the results of research conducted by the author, the authors suggest that the use of Virtual Learning Laboratory not only in physics but also in other subjects at school. There are several advantages in the use of the Virtual Lab:

1. Computer simulations have the ability to present a realistic visualization and image.

2. Using virtual simulation lab before practicing can improve learning outcomes.

3. The effectiveness of simulation depends on the order of presentation of student learning activities.

4. The cost of labor tool is much more expensive than the cost of a virtual lab

5. The computer-based simulations can create a constructive learning environment.

6. The time is used more efficient

\section{REFERENCES}

Akpan, J. P. (2001). Issues associated with inserting computer simulation into biology instruction: a review of literature. Electronic Journal of Science Education, 5(3).

Arikunto, S. (1990). Manajemen Pengajaran Secara Manusiawi. Jakarta : Rineka Cipta.

Dimyati \& Mudjiono. (1999). Belajar dan Pembelajaran. Jakarta: Rineka Cipta.

Hamalik, O. (2001). Proses Belajar Mengajar. Jakarta: Bumi Aksara.

Hilgart, E. R. \& Bower, G. H. (1975), Theory of Learning. Englewood Chiffs: New Jersey Prentice Hall Inc.

Indrawati.

(1999).

Model-Model

Pembelajaran IPA. Bandung: Dirjen Dikdasmen P3G IPA.

NSTA (1998). Standar for Science Teacher Preparation, NSTA and AETS.

Romizowski, A. J. (1981). Design Instructional System, London: Kogan Page Ltd.

Snelbecker, G. E. (1974). Learning Theory and Instructional, Theory and Psychoeducational Design. New York: Mc-Graw Hill Inc Company.

Suyatna, A. (2005). Simulasi Praktikum Menggunakan Perangkat Lunak Program Crocodile untuk Meningkatkan Kemampuan Analisis dan Desain Rangkaian Elektronika. Bandung: Program Studi Pendidikan IPA-PPS UPI. Proceeding

Winkel, W. S. (1991). Psikologi Pengajaran. Jakarta: Gramedia Widiasarana Indonesia.

Wiriaatmaja, R. (2005). Metode Penelitian Tindakan Kelas, Bandung: Remaja Rosdakarya dan Universitas Pendidikan Indonesia Press.

www. kurtek.upi.edu/media/. 